\title{
The Differences of Mathematics Learning Outcomes between Think Pair Share (TPS) and Number Heads Together (NHT)
}

\author{
Arie Purwa Kusuma ${ }^{1}$, Maskuroh Maskuroh ${ }^{2}$ \\ ${ }^{1,2}$ STKIP Kusumanegara, Jakarta Timur \\ ${ }^{1}$ Correspondence Address; Arie_pk@stkipkusumanegara.ac.id
}

\begin{abstract}
The low learning outcomes of mathematics are not appropriate thought of learning models in the classroom. Therefore, the NHT and TPS learning models can be applied to improve the learning of outcomes of the student. This study aims to determine the differences in learning outcomes using the NHT learning model with the TPS learning model. The sampling technique is used as a random sampling cluster with 2 groups of experiments for the first experimental group (classroom view of TPS model) and the second experimental group (classes of NHT modeling). The instrument of this research uses the test of mathematics learning result. The hypothesis test is used T-Test. The conclusion of research that are differences in the outcomes of the two learning models (NHT and TPS) on learning outcomes, based on the marginal mean of the TPS learning model is better learning outcomes than the NHT learning model.
\end{abstract}

Keyword: Learning Outcomes; Number Heads Together; Think Pair Share.

\section{INTRODUCTION}

One of Indonesian Purpose in the opening of the 1945 State's Basic Law of the Indonesian Republic is to educate of the nation. The achievement of a national goal to educate the nation is done through education toon. Education involves the activities of learning and the learning process. According to Mulya in (Kusuma, 2017) as one of the processes of learning, the teacher is always required to improve the quality of learning. from the aspect of the process and results. In terms of process, the teacher can be said successful if able to involve most learners actively, both physically, mentally, and socially in learning, while in terms of results, The Teacher is said successful if it can change the behavior of most learners towards the mastery of competence basics well are mainly from the students' learning outcomes. Referring to the success of the teacher in terms of results, several types of research have commented that students' learning outcomes in the past three years have not improved (Amiluddin \& Sugiman, 2016; Astuti, Yuanita, \& Anggraini, 2018). This is influenced by several factors that affect student achievement, especially VII class students in the learning mathematics. The Internal factors that influence the student's learning outcomes of the students' mathematical communication ability in learning the subject, while the external factor is the way of the teaching teacher, or the learning model that is used by the teacher in the classroom learning (Chrissanti \& Widjajanti, 2017). Meanwhile, according to Mujib (2016), the learning model used in learning mathematics that influences the mathematical learning outcomes of learners.

Based on some issues above, it is certainly inclusive in the learning of mathematics. The evaluation of the researcher with some relevant research, it is suggested that the learning model 
has been used by the teacher in class does not appropriate, the result of the learning outcomes is unstratified. Therefore, a proper learning model is needed in The teaching material. According to According to Surayya, et al (2014), learning model of think pair share (TPS) can improve students' thinking skill. In addition, according to Ni'mah \& Dwijananti (2014) learning model of type TPS can improve learning outcomes and learning activities of learners. The TPS model is one type of cooperative learning model. Think Pair Share cooperative learning (TPS) is a group learning model where students are given more time thinking about the answers and helping each other. The procedure is used also quite simply because in the group only consists of two people (Jannah, Saputro, \& Yamtinah, 2013). In addition to the TPS type learning model, cooperative learning model type NHT (number head together) is also a model that is able to make students motivated in learning math. NHT learning model can reduce the anxiety of learners who always have an impact on learning outcomes in learning mathematics (Ardiawan, Budiyono, \& Subanti, 2013; Winarni, Budiyono, \& Sari, 2013). NHT learning model is a learning model designed to influence the pattern of student interaction, the goal is to increase academic mastery of learners. In the NHT type cooperative model, each student is given the opportunity to share ideas and consider the most appropriate answer. In addition, every student will be motivated to improve their spirit of cooperation. NHT type cooperative learning can be used in all subjects and for all ages of learners (Ardiawan et al., 2013).

Each of both models can improve the learning outcomes of the student. but both models have a more significant effect in improving learning outcomes of the student. So the researcher is interested in doing research for looking at the difference between the cooperative model of NHT and TPS on the learning outcomes of learners.

\section{THE RESEARCH METHODS}

The research method has been used in this research is using experimental research. The collecting data technique using the mathematical learning result test instrument. This test is used to obtain data about student learning outcomes. Prior to hypothesis testing, the prerequisite analysis is done on the students' initial ability of each class taken from the UAS grade of the odd semester for the balance test with significance level of 0.05 . The prerequisite analysis test is normality test and homogeneity test. if the result is normal and homogenous, then tested the statistical hypothesis using t-test.

\section{THE RESULTS OF THE RESEARCH AND THE DISCUSSION}

After the Students' learning outcomes were collected from both experiment classes 1(The treatment of TPS learning models) and from Experiment class 1(The Treatment of NHT learning model ) were obtained: 
Table 1. The Description Data of students learning the result

\begin{tabular}{cccccc} 
Class & $\mathbf{X}_{\text {maks }}$ & $\mathbf{X}_{\text {min }}$ & \multicolumn{3}{c}{$\begin{array}{c}\text { Central Tendency size } \\
\text { Me }\end{array}$} \\
& & & & Mo \\
\hline Experiment 1 & 85 & 45 & 76,55 & 75 & 75 \\
Experiment 2 & 65 & 30 & 55,69 & 45 & 40 \\
\hline
\end{tabular}

Furthermore, the analysis of the normality test of the student learning outcomes in the experimental group 1 and experimental group 2. The following recapitulation results of students' learning outcomes in experimental class 1 and experiment class 2 :

Table 2. The Calculation Result of Normality Test

\begin{tabular}{lcccc} 
Class & The Number of Samples & $\left.\mathbf{L h i t u n g}_{(\mathbf{L}(\mathbf{a}, \mathbf{n})}\right)$ & $\mathbf{L}_{\text {tabel }}$ & Description \\
\hline Experiment 1 & 30 & 0,1117 & 0,1454 & Normal \\
\hline Experiment 2 & 30 & 0,1016 & 0,1556 & Normal \\
\hline
\end{tabular}

Based on Table 2, it can be concluded that the data obtained from each group which comes from a normally distributed population. Based on Table 2, it can be concluded that the data obtained from each group which comes from a normally distributed population.

Based on the homogeneity test of population variance on learning result data of The mathematics Students, obtained $\chi_{o b s}^{2}=2,4184$ less than value $\chi_{o b s}^{2}=5,991$. It means that at the 0.05 significance level, the decision on homogeneity test of population variance is $\mathrm{H}_{0}$ accepted, so that it can be concluded that the comparable populations, that is, the experimental group 1 and the experimental group 2 have the same variance (homogeneous).

Furthermore, hypothesis testing (t-test) is used to test the difference in learners' mathematical learning outcomes. The calculation results can be seen in Table 4. below:

Table 3.The Results of T-Test

\begin{tabular}{lcccc} 
Class & Average & $\mathbf{t}_{\text {table }}\left(\mathbf{t}_{\mathbf{a}, \mathbf{d b}}\right)$ & $\mathbf{t}_{\text {count }}$ & Description \\
\cline { 1 - 2 } Experiment 1 & 30 & 2,109 & 14,333 & Reject $\mathrm{H}_{0}$ \\
\hline Experiment 2 & 30 & & & \\
\hline
\end{tabular}

Based on Table 3., it is obtained thitung $=14,333>\mathrm{t}_{\text {table }}=2,109$ which means $\mathrm{H}_{0}$ is rejected, it means that there is a difference of outcome between the TPS learning model and the NHT learning model.

From the average of the students learning outcomes can be seen in table 3 obtained experimental class 1 (TPS learning model) obtained a value of 71.985 which while the class Experiment 2 (NHT Learning Model) obtain 65,013, It means that the Mathematics Student's learning outcomes between the experimental class 1 (classes treated with TPS) are better than the 
experimental class 2 (classes treated with the NHT model). The results of this study are suspected because in learning TPS, the student looks more active in learning than in learning NHT. In theory of the TPS learning model also has advantages when sharing information among the student. The results of this research are also in line with the previous research with the result that the TPS research model can help the student in contextual learning process or relate learning in real life, in addition, NHT learning model can help learners to understand the ability of the concept and make the student more creative in learning mathematics (Fristady, Noer, \& Djalil, 2014; Jannah et al., 2013; Kusumaningrum, Budiyono, \& Subanti, 2015; Nugraha \& Masykuri, 2013)

\section{CONCLUSION AND SUGGESTION}

Based on the theory and supported by the results of analysis and data processing and refers to the formulation of problems that have been described, it can be concluded that: there are differences in the outcomes of student's mathematics learning with using of models TPS (think

pair share) with using of NHT model (number head together). Furthermore, mathematics learning outcomes of the student with using of TPS model (think pair share) is better than the outcomes of student's learning mathematics on the material of set number with using of learning model NHT (number head together). Based on the conclusions, the researcher suggests that The teacher have to use the TPS learning model (think pair share) in the classroom to improve students' learning outcomes.

\section{REFERENCES}

Amiluddin, R., \& Sugiman, S. (2016). Pengaruh problem posing dan PBL terhadap prestasi belajar, dan motivasi belajar mahasiswa pendidikan matematika. Jurnal Riset Pendidikan Matematika, 3(1), 100-108.

Ardiawan, Y., Budiyono, B., \& Subanti, S. (2013). Efektivitas Model Kooperatif Tipe NHT dengan PMR dan Model Kooperatif Tipe GI dengan PMR terhadap Prestasi Belajar Matematika Ditinjau dari Kreativitas Siswa.

Astuti, R. P. S., Yuanita, P., \& Anggraini, R. D. (2018). Pengaruh Penerapan Pendekatan Pembelajaran Matematika Realistik (Pmr) Terhadap Kemampuan Pemecahan Masalah Matematika Siswa Kelas VII SMP Muhammadiyah 1 Pekanbaru. Jurnal Online Mahasiswa (JOM) Bidang Keguruan Dan Ilmu Pendidikan, 5(1), 1-13.

Chrissanti, M. I., \& Widjajanti, D. B. (2017). Keefektifan pendekatan metakognitif ditinjau dari prestasi belajar, kemampuan berpikir kritis, dan minat belajar matematika. Pythagoras: Jurnal Pendidikan Matematika, 12(2). https://doi.org/10.21831/pg.v12i2.17712 
Fristady, R., Noer, S. H., \& Djalil, A. (2014). Efektivitas Model Pembelajaran Kooperatif Tipe TPS Terhadap Pemahaman Konsep Matematis Siswa. Jurnal Pendidikan Matematika Unila, 2(7).

Jannah, R., Saputro, A. N. C., \& Yamtinah, S. (2013). Penerapan model pembelajaran Think Pair Share (TPS) disertai buku saku untuk meningkatkan aktivitas dan prestasi belajar kimia pada materi minyak bumi kelas X SMA Negeri Gondangrejo tahun pelajaran 2012/2013. Jurnal Pendidikan Kimia, 2(4), 19-23.

Kusuma, A. P. (2017). Implementasi Model Pembelajaran Student Teams Achievement Division dan Team Assisted Individualization ditinjau dari Kemampuan Spasial Siswa. Al-Jabar : Jurnal Pendidikan Matematika, 8(2), 135-144.

Kusumaningrum, R., Budiyono, B., \& Subanti, S. (2015). Eksperimentasi Model Pembelajaran Kooperatif Tipe Two Stay Two Stray (TSTS), Numbered Heads Together (NHT), Dan Think Pair Share (TPS) Pada Materi Lingkaran Ditinjau Dari Kreativitas Belajar Matematika Siswa SMP Negeri Di Kabupaten Sukoharjo.

Mujib, M. (2016). Komunikasi Matematis Siswa Tunarungu dalam Pembelajaran Matematika Didasarkan pada Teori Schoenfeld. Al-Jabar : Jurnal Pendidikan Matematika, 7(1), 8590.

Ni'mah, A., \& Dwijananti, P. (2014). Penerapan Model Pembelajaran Think Pair Share (TPS) dengan Metode Eksperimen untuk Meningkatkan Hasil Belajar dan Aktivitas Belajar Siswa Kelas VIII MTs. Nahdlatul Muslimin Kudus. UPEJ Unnes Physics Education Journal, $3(2)$.

Nugraha, D. A., \& Masykuri, M. (2013). Efektivitas Metode Pembelajaran Kooperatif Think Pair Share (TPS) yang Dilengkapi Media Kartu Berpasangan (Index Card Match) terhadap Prestasi Belajar Siswa pada Materi Ikatan Kimia Kelas X Semester Gasal SMA N 2 Karanganyar Tahun Pelajaran 2012/2013. Jurnal Pendidikan Kimia, 2(4), 174-181.

Putra, F. G. (2016). Pengaruh Model Pembelajaran Reflektif dengan Pendekatan Matematika Realistik Bernuansa Keislaman terhadap Kemampuan Komunikasi Matematis. Al-Jabar : Jurnal Pendidikan Matematika, 7(2), 203-210.

Surayya, L., Subagia, I. W., \& Tika, I. N. (2014). Pengaruh model pembelajaran think pair share terhadap hasil belajar IPA ditinjau dari keterampilan berpikir kritis siswa. Jurnal Pendidikan IPA Indonesia, 4(1).

Winarni, D., Budiyono, B., \& Sari, D. R. (2013). Eksperimentasi Model Pembelajaran Numbered Heads Together (Nht) Dan Think Pair Share (Tps) Dengan Pendekatan Contextual Teaching and Learning (Ctl) Pada Pokok Bahasan Limit Fungsi Ditinjau Dari Kecemasan 


\section{$\mathbf{a} \rho \rho$}

Al-Jabar: Jurnal Pendidikan Matematika Vol. 9, No. 1, 2018, Hal 19 - 24

Belajar Matematika (Penelitian Dilaksanakan Di SMA. Jurnal Pembelajaran Matematika, 1(5), 490-500. 